\title{
Impact of Inflation and City Minimum Wages on Human Development Index in Indonesia
}

\author{
Herman \\ Sekolah Tinggi Ilmu Ekonomi Riau \\ Jln. HR Subrantas KM 12 Tel (0761) 63237 Fax (0761) 63366 \\ E-mail : herman@1ecturer.stieriau-akbar.ac.id
}

\begin{abstract}
The aim of this study to knowing the impact of inflation and the city's minimum wage on the human development index in the city of Pekanbaru. The data used are Human Development Index, Inflation, and City Minimum Wages from 2010 to 2020. The data were analyzed using SPSS Version 25. The findings of this study are partially, inflation has no effect on the human development index in the city of Pekanbaru, while the city's minimum wage has a significant effect on the human development index in the city of Pekanbaru. while simultaneously that inflation and the city's minimum wage affect the human development index in the city of Pekanbaru. and the magnitude of the effect of inflation and the city's minimum wage on the human development index in Pekanbaru city of $98.8 \%$, the remaining $1.20 \%$ by other variables not included in this study.
\end{abstract}

Keywords: Human Development Index, Inflation, City Minimum Wage.

\section{INTRODUCTION}

The development in Pekanbaru City has a goal to improve the welfare of everyone, both the level of income, education, health, consumption, and others. In order to realize Pekanbaru as a civilized metropolitan city, the government should increase independent and competitive human resources, in this case the human development index in Pekanbaru City should be the main focus. The human development index describes how the population can access development outcomes in terms of income, health, education, and so on. This illustrates the government's performance in order to describe the ranking or level of development of a region/country(Iskamto 2012).

In the book Policy for Increasing the Human Development Index (IPM) in Indonesia (2018) by Yusniah Anggraini, it is explained that the HDI has three dimensions that are used as the basis for its calculation, namely: longevity, knowledge or education, and a decent standard of living (number of people working). Based on the results of research conducted by Herman (2018), that the education level of the Pekanbaru City community is dominated by the high school education level, which is 39.03 percent while for universities it is only 13.33 percent where the population of Pekanbaru City always increases, then this will have an impact on existing human development index problems(Iskamto et al. 2021).

A high inflation rate is a good and bad picture of the economic problems faced by a country. In any economy, inflation cannot be avoided, but it should be noted that the inflation rate should not continue to reach a level that worries the public. The following is data on inflation, UMK, and Pekanbaru City HDI from 2010 to 2020, which are as follows:

Table.1. Data on Inflation, UMK, and HDI

\begin{tabular}{cccc}
\hline Year & Inflation Growth /Dec & MSE & HDI \\
\hline 2010 & -0.10 & $1,055,000$ & 77.34
\end{tabular}




\begin{tabular}{ccrc}
2011 & 1.33 & $1,135,000$ & 77.71 \\
2012 & 0.69 & $1,260,000$ & 77.94 \\
2013 & 0.41 & $1,450,000$ & 78.16 \\
2014 & 0.38 & $1,775,000$ & 78.42 \\
2015 & 1.69 & $1,925,000$ & 79.32 \\
2016 & 0.27 & $2,146,375$ & 79.69 \\
2017 & 0.48 & $2,352,577$ & 80.01 \\
2018 & 0.27 & $2,557,487$ & 80.66 \\
2019 & -0.22 & $2,997,972$ & 81.35 \\
2020 & -0.21 & $2,997,976$ & 81.32 \\
\hline \multicolumn{4}{r}{ Source BPS Pekanbaru City, 2021}
\end{tabular}

Based on table 1 above, it can be explained that the inflation growth of Pekanbaru City in 2010 was -0.10 percent and increased to 1.33 percent in 2011 . According to the quantity theory, that if the quantity of goods supplied remains constant, while the amount of money is doubled, then sooner or later the price will double. It can be seen that the city's minimum wage rose from $1,055,000$ to $1,135,000$ wherein the human development index only rose by 0.37 percent. So the table above illustrates that the increase in the city's minimum wage each year is quite large, while the human development index is not so large in its increase. Based on the problems above, it is interested in conducting research with the title "Impact of Inflation and City Minimum Wage on the HDI of Pekanbaru City (2010-2020)".

\section{LITERATURE REVIEW}

\section{Human Development Index (HDI)}

Human Development Index (HDI) is a composite that is used to measure the average achievement of a country in three basic aspects of human development, namely: length of life, education and standard of living. The index value ranges from 0-100, where HDI measures the overall achievement of a region or country in three basic dimensions of human development, namely length of life, knowledge and a decent standard of living.(Iskamto, Ghazali, and Aftanorhan 2019).

The Human Development Index is an index that measures the achievement of a country's socioeconomic development, which combines achievement in the fields of education, health and adjusted real income per capita. According to the United Nations Development Program (UNDP), in Indah, 2018:74 The Human Development Index (HDI) measures human development achievements based on a number of basic components of quality of life. As a measure of quality of life. The Human Development Index (HDI) is built through a basic three-dimensional approach. The basic dimensions include: a. Long and healthy life (a long and healthy life). b. Knowledge (knowledge). c. Decent standard of living.

\section{Inflation}

The short definition of inflation is the tendency of prices to rise generally and continuously. An increase in just one or two goods is not called inflation, unless the increase extends to (resulting in an increase) a large proportion of the prices of other goods. Inflation is a process of increasing prices prevailing in an economy (Sadono Sukirno: 2016).

Meanwhile, according to Julius (2011: 22) states that the definition of inflation is as follows: "A brief definition of inflation is the tendency of prices to rise continuously". 
M. Natsir (2014) states that the definition of inflation is as follows: "Inflation is a tendency to increase the prices of goods and services in general and continuously". According to Hamilton in Erika (2020) inflation has been widely described as an economic situation when the increase in the supply of money is "faster" than the production of goods and services in the same economy. The inflation rate is measured as a percentage change in price indices (consumer price index, wholesale price index, producer price index etc.) Inflation is the tendency of prices to increase in general and continuously over a long period of time. An increase in the price of one or two goods is not called inflation, unless the increase extends to (or results in an increase in) some greater than the price of other goods (Budiono in Rahma.

\section{City Minimum Wage (UMK)}

In the Government Regulation of the Republic of Indonesia Number 78 of 2015 concerning Wages article 1 paragraph (1), wages are defined as the rights of workers/laborers received and expressed in the form of money as a reward from the entrepreneur or employer to the worker/labourer which is determined and paid according to an agreement. work, agreement, or statutory regulations including allowances for workers/laborers and their families for a job or service that has been or will be performed. Wages are rewards received for a month by workers or employees in the form of money or goods paid by the company/office/employer (BPS Sumsel 2012).

Minimum Wage is the lowest monthly wage consisting of basic wages including fixed allowances set by the governor as a safety net. The minimum wage is determined by the governor by taking into account the recommendations from the Provincial Wage Council and or the Regent/Mayor. components as well. implementation of the stage of achieving decent living needs is regulated by a Ministerial Decree. The sectoral minimum wage can be set for groups of business fields and their distribution according to the classification of Indonesian business fields for districts/cities, provinces, several provinces or nationally and must not be lower than the regional minimum wage of the area concerned. Economic theory defines wages as payments for the physical and mental services provided by labor to employers, Thus, in economic theory, there is no distinction between payments to permanent employees and payments to non-permanent employees. (Sukirno, in Rini, 2012:200). From the several definitions of wages above, it can be concluded that wages are rewards received by workers from employers for services provided to companies based on the length of hours worked and the number of products produced, as well as an agreement between workers and employers in determining the amount of wages.

\section{conceptual framework}

\section{INFLATION}

$\operatorname{MSE}(\mathrm{X} 2)$

HDI (Y)

Hypothesis:

1.Inflation affects HDI

2. MSEs have an effect on HDI

3.Inflation and UMK affect HDI 
Research variable

1. Inflation (\%) UMK (Rp) as the independent variable (X).

2.IPM (\%) As dependent variable (Y)

\section{METHOD}

This research conducted in Pekanbaru City in 2010-2020. Type of research is descriptive and quantitative. data collection techniques using secondary data during the period 2010-2020, namely from the Central Bureau of Statistics of Pekanbaru City. Data processing using SPSS version 25.

\section{RESULTS AND DISCUSSION}

\section{Descriptive Analysis}

Table 2 Descriptive Statistics

\begin{tabular}{lrrr}
\hline & \multicolumn{4}{c}{ mean } & Std. Deviation & \multicolumn{1}{c}{$\mathrm{N}$} \\
\hline HDI & 79.27 & 1,452 & 11 \\
INFLATION & .46 & .600 & 11 \\
MSE & 1.9684 & 7.06049 & 11 \\
\hline
\end{tabular}

Based on table 2 above, it can be explained that the average human development index is 79.27 percent, inflation is 0.46 percent, and the City Minimum Wage is Rp. 1,968,400.

\section{Model Interpretation}

Table 3. Multiple Linear Regression

\begin{tabular}{|l|l|r|r|}
\hline \multicolumn{2}{|c|}{ Model } & \multicolumn{2}{c|}{$\begin{array}{c}\text { Unstandardized } \\
\text { Coefficients }\end{array}$} \\
\cline { 3 - 5 } \multicolumn{2}{|c|}{} & \multicolumn{1}{c|}{ B } & \multicolumn{1}{c|}{ Std. Error } \\
\hline \multirow{2}{*}{1} & (Constant) & 75.083 & .209 \\
\cline { 2 - 5 } & INFLATION & .137 & .105 \\
\cline { 2 - 5 } & MSE & 2,093 & .000 \\
\hline
\end{tabular}

a. Dependent Variable: HDI

$\mathrm{Y}=75,083+0,137$ Inflation $+2,093 \mathrm{UMK}$

From the above equation, it can be concluded that: If inflation and UMK in Pekanbaru city are 0 or not at all, then the human development index is at a constant value of 75,083. If inflation increases by one unit, then the human development index will increase by 0.137 . and if the city's minimum wage increases by one unit, the human development index will increase by 2,093 units.

\section{Test Partial Significance}

Table 4. Test Partially

\begin{tabular}{|l|l|r|r|}
\hline \multicolumn{2}{|l|}{} & \multicolumn{1}{l|}{$\mathrm{t}$} & \multicolumn{1}{l|}{ Sig. } \\
\hline \multirow{3}{*}{1} & (Constant) & 358,671 & .000 \\
\cline { 2 - 4 } & INFLATION & 1.305 & .228 \\
\cline { 2 - 4 } & MSE & 23,378 & .000 \\
\hline
\end{tabular}




\section{a. Dependent Variable: HDI}

Based on table 4 above, it can be explained: It is found that the t-value for the inflation variable is 1.305 while the t-table value is 1.833 . and the value of Sig. shows a value of 0.228 so it is concluded that inflation has no effect on the human development index in Pekanbaru City. These results support the research conducted by Sukma Febrianti and Junita Indriyanti that inflation has no effect on the human development index.It was found that the $t$ value for the City Minimum Wage variable was 23,378 while the $t$ table value was 1,833 . and the value of Sig. show value of 0.000 so that concluded that the City Minimum Wage has a significant effect on the human development index in Pekanbaru City. These results support the research conducted bySiska Ardi that the City Minimum Wage has a significant effect. From the results of the partial analysis, that the City minimum wage variable has a significant effect on the human development index, this is because the increase in the city's minimum wage each year is quite large, so that it has an impact on the human development index in the city of Pekanbaru.

4. Simultaneous Significance Test

Table 5. Simultaneous Test

\begin{tabular}{|c|c|c|c|c|}
\hline Model & & $\begin{array}{l}\text { mean } \\
\text { Square }\end{array}$ & $\mathrm{F}$ & Sig. \\
\hline 1 Regression & 2 & 10,407 & 325,669 & $.000 \mathrm{a}$ \\
\hline Residual & 8 & .032 & & \\
\hline Total & 10 & & & \\
\hline
\end{tabular}

a. Predictors: (Constant), MSE, INFLATION

b. Dependent Variable: HDI

Based on table 5 above, it shows that the calculated $F$ is 325,669 with a sig of 0.000 , while the $\mathrm{F}$ table is 4.46 . It can be seen that Fcount $>$ Ftable with a value of $325,669>4.46$ with a significant value of $0.000<0.05$ which means inflation, and the city's minimum wage has a significant effect on the human development index in the city of Pekanbaru.

\section{Coefficient of Determination Test}

Table 6. Coefficient of Determination
\begin{tabular}{|l|r|c|c|}
\hline & & $\mathrm{R}$ & Adjusted R \\
Model & $\mathrm{R}$ & Square & \multicolumn{1}{c|}{ Square } \\
\hline 1 & .994 & .988 & \\
& $\mathrm{a}$ & & \\
\hline
\end{tabular}

a. Predictors: (Constant), MSE, INFLATION

b. Dependent Variable: HDI

Based on table 6 above, it can be seen that the Adjusted R Square value is 0.988 or $98.8 \%$ which means that the independent variable is able to explain the dependent variable, namely inflation, and 
the city's minimum wage, amounting to $98.8 \%$ while the remaining $1.20 \%$ is influenced by by other variables not analyzed in this study.

1. The Effect of Inflation on the Human Development Index

Based on the results of the study, it was found that inflation had no significant effect on the human development index in the city of Pekanbaru. The results of this study are in line with research conducted by Sukma Febrianti and Junita Indriyanti, 2020, The Effect Of InfLation, Poverty, And Investment On Sustainable Development In West Kalimantan province that inflation has no significant effect on development.

2. Effect of City Minimum Wage on Human Development Index

Based on the results of the study, it was found that the city's minimum wage had a significant effect on the development index of the city of Pekanbaru. The results of this study are in line with the results of research conducted by Siska Ardi, 2020, Journal of Development Economics, The Effect of Regional Minimum Wage and Inflation on HDI in Central Java. that Real MSE and inflation have a significant positive effect on the HDI of Central Java Province.

3. The Effect of Inflation and City Minimum Wages on Human Development Index

Based on the results of the study, it was found that the variables of inflation and minimum wages had a simultaneous effect on the human development index. The results of this study are in line with the results of research conducted by Siska Ardi, 2020, Journal of Development Economics, The Effect of Regional Minimum Wage and Inflation on HDI in Central Java.that Real MSE and inflation have a significant positive effect on the HDI of Central Java Province.

\section{CONCLUSION}

Based on the results of the research that has been done, the conclusion in this case is partially, inflation has no effect on the human development index in the city of Pekanbaru, while the city's minimum wage has a significant effect on the human development index in the city of Pekanbaru. while simultaneously that inflation and the city's minimum wage affect the human development index in the city of Pekanbaru. and the magnitude of the effect of inflation and the city's minimum wage on the human development index in Pekanbaru city of $98.8 \%$, the remaining $1.20 \%$ by other variables not included in this study.

\section{REFERENCES}

Badan Pusat Statistik, 2015.“Indeks Pembangunan Manusia 2014 Metode Baru”, (Banten: BPS Provinsi Banten.

Erika, 2020. Pengaruh Inflasi Terhadap Pertumbuhan Ekonomi Di Indonesia, Journal Of Management (Sme's) Vol. 13, No.3, 2020, p327-340. DOI: https://doi.org/10.35508/jom.v13i3.3311.

Herman, 2018, Pengaruh Tingkat Pendidikan Dan Jumlah Penduduk Terhadap Tingkat Kemiskinan Di Kota Pekanbaru. Jurnal Uquilibrium, Vol 6 No. 2.

DOI: http://doi.org/10.25273/equilibrium.v6i2.2936 
Iskamto, Dedi. 2012. "Persoalan Sumber Daya Manusia Dalam Pengembangan Ekonomi Islam." Eko Dan Bisnis (Riau Economics and Business Review) 3(1).

Iskamto, Dedi, Puspa Liza Ghazali, and Asyraf Aftanorhan. 2019. "Effect Contextual Factor Toward Entrepreneurial Intention Among Young Educated." P. 7 in International Conference on Industrial Engineering and Operations Management Riyadh. Saudi Arabia.

Iskamto, dedi, Arhipen Yapentra, Elida Gultom, Misdawati, Wetri Febrina, Budi santosa, and A. T. Bon. 2021. "The Exploratory Factor Analysis on Firms Performance of Micro and Small Enterprises." in Proceedings of the 11th Annual International Conference on Industrial Engineering and Operations Management. Singapore: IEOM Society International.

Julius R. Latumaerissa. 2011, Bank dan Lembaga keuangan lain, Salemba Empat: Jakarta.

Natsir, Muhammad, 2014. Ekonomi Moneter dan Kebanksentralan, Mitra Wacana Media. Jakarta.

Peraturan Pemerintah Republik Indonesia Nomor 78 Tahun 2015 Tentang Pengupahan, Bab I (Ketentuan Umum) pasal 1.

Rahma, 2019. Jurnal Akuntansi Muhammadiyah, Vol 9, No. 2. Universitas Serambi Mekkah.

Rini Silistiawati, 2012, Pengaruh Upah Minimum terhadap Penyerapan Tenaga Kerja dan Kesejahteraan Masyarakat di Provinsi di Indonesia. Eksos, Volume 8, Nomor 3. Universitas Tanjung pura Pontianak

Sadono Sukirno. 2016, Teori Pengantar Makro Ekonomi Edisi Ketiga. Rajawali Pers: Jakarta.

Siska Ardi Cahyati, 2020, The Effect of Regional Minimum Wage and Inflation on HDI in Central Jawa. Jurnal Ekonomi Pembangunan, Vol. 18, No. 02, December 2020. DOI: https://doi.org/10.22219/jep.v18i2.12869

Sukma Febrianti dan Junita Indriyati. 2020, The Effect Of InfLation, Poverty, And Investment On Sustainable Development In West Kalimantan province. Jurnal Ekonomi dan Manajemen. Vol.14 No.1.2020. DOI: https://doi.org/10.30650/jem.v14i1.1310

UNDP. (2018). Funding Compendium 2017. New York: United Nations Development Programme.

United Nation Development Program (UNDP). (1990). Human Development Report 1990. New York: Oxford University Press.

Yusniah Anggraini 2018. Kebijakan Peningkatan Indeks Pembangunan Manusia di Indonesia. 